\title{
Perception and Satisfaction of Residents with the Impact of the Protected Area on Sustainable Tourism - the Case of Deliblatska Peščara Special Nature Reserve, Serbia
}

\author{
Igor Trišić ${ }^{A^{*}}$, Snežana Štetić ${ }^{B}$, Marija Maksin' ${ }^{C}$, Ivana Blešić ${ }^{D E}$ \\ Received: July 19, 2021 | Revised: October 20, 2021 | Accepted: October 21, 2021 \\ doi: $10.5937 / g p 25-33196$
}

\begin{abstract}
In the Deliblatska Peščara Special Nature Reserve (SNR) there are a large number of natural and social factors that affect the development of tourism. Such are: rare and endangered endemic flora and fauna that are important in the procedures of species protection, ecosystem, wetlands, socio-cultural heritage, the possibility of developing specific forms of tourism and other factors. The SNR has a relief that is present only in this protected area - dunes. This type of sand has influenced the specific flora and fauna that cannot be found in other areas. There are 18 settlements in the reserve that have significant cultural, monumental and archaeological heritage. The research aims to determine the satisfaction of residents with the function of the SNR in sustainable tourism development using a quantitative methodology and SPSS software. The responses from 510 residents indicate their satisfaction with the development of sustainable tourism in the SNR through ecological, economic and institutional sustainability of this tourism destination.
\end{abstract}

Keywords: sustainable tourism; Deliblatska Peščara Special Nature Reserve; residents' satisfaction; protected area

\section{Introduction}

Sustainable tourism development is defined as a positive impact on all subjects of tourism development, i.e. the development that contributes to the ecological, economic and socio-cultural sustainability of a tourism destination (Spangenberg, 2002; Trišić et al., 2021). Thus, it is necessary to examine the impact of tourism on nature and the improvement of its elements (Ceron \& Dubois, 2003; Stojanović et al., 2021). Economic sustainability refers to different benefits for residents through the development of tourism forms that clearly define their role. Different forms of tourism contribute to higher employment of residents, local products and services can be better promoted and available to tourists, the satisfaction of residents and tourists contributes to higher tourists' visits and therefore, to higher tourist con-

\footnotetext{
A University of Belgrade, Faculty of Geography, trisici@hotmail.com

B Balkan Network of Tourism Experts, snezana.stetic@gmail.com

C Institute of Architecture and Urban \& Spatial Planning of Serbia, Belgrade, Serbia, micic70a@yahoo.com

D University of Novi Sad, Faculty of Sciences, Department of Geography, Tourism and Hotel Management, Trg Dositeja Obradovića 3, 21000 Novi Sad, ivana.blesic@dgt.uns.ac.rs

E South Ural State University, Institute of Sports, Tourism and Service, 76 Lenin Ave., Chelyabinsk 454080, Russia

* Corresponding author: Igor Trišić, e-mail: trisici@hotmail.com
} 
sumption (Trišić et al., 2020; Obradović et al., 2021; Obradović \& Stojanović, 2021).

Positive attitudes of tourists and residents towards the development of tourism that improves social and cultural values of a tourism destination indicate that positive socio-cultural impacts of sustainable tourism development have been achieved (Bello et al., 2016; Stojanović et al., 2018). Sustainable tourism development can contribute to the benefits for tourists, residents, managers, the state and the tourism destination, through economic, environmental, institutional and socio-cultural sustainability (Font et al., 2003; Štetić et al., 2019; Obradović et al., 2021; Obradović \& Stojanović, 2021).

If we examine the impact of tourism on sustainable tourism development in protected natural areas as specific tourism destinations with natural and cultural heritage, it is essential to study residents' attitudes and satisfaction (Sæpórsdóttir \& Hall, 2021) with the condition of sustainability in a specific tourism destination (McCool et al., 2001; Twining-Ward and Butler, 2002; Buckley, 2003; Queiroz et al., 2014; Lee \& Hsieh, 2016; Agyeiwaah et al., 2017; Vučetić, 2018; Obradović et al., 2020).

Eagles (2002) emphasizes the importance of the following tourism factors for the sustainable development of tourism within protected areas: ecosystem, land, vegetation, water, air and wildlife. These are the resources by which proper management and monitoring (Maksin et al., 2018) can preserve space and species, improve protection systems and models and with which the development of adequate sustainable tourism activities can be planned within these destinations with sensitive ecosystems (Hall, 2009; Jojić-Glavonjić, 2018). In addition to the basic tourist attraction, the development of sustainable tourism can be influenced by other factors such as space protection (Pavić et al., 2016), space use intensity, carrying capacity, the role of the local community in tourism development, socio-cultural impacts, tourism contribution to the local economy, control development, waste management and others (Chin et al., 2000; Choi \& Sirakaya, 2006; Schianetz \& Kavanagh, 2008; Chávez-Cortés \& Maya, 2010; Tanguay et al., 2013).

The aim of the research in this paper is to examine the extent to which the residents of seven significant settlements from the area of the SNR are satisfied with the state of sustainable tourism development. Also, the aim is to identify weaker aspects of sustainability according to the obtained results, based on the appropriate measures planned to improve sustainable tourism. Applying quantitative methodology the authors analyze the responses of 510 residents who expressed their perceptual attitudes towards sustainable tourism using a five-point Likert scale in the questionnaire. Residents' responses may indicate the importance of protected natural areas for preserving ecological (Aquino, 2019), economic, sociocultural, and institutional sustainability (Sharpley, 2000; Asmelash \& Kumar, 2019; Trišić, 2020). The results of the survey can be used to develop strategies for sustainable tourism development, future research on the importance of protected natural areas for the development of tourism destinations and the improvement of sustainable tourism conditions in protected natural areas.

\section{Data and methods}

\section{Study area}

The SNR is located in the south-eastern part of Vojvodina (north-eastern Serbia) and it covers a habitat of about 35,000 ha, of which 34,829 ha is the SNR (Kovačev, 2014). This nature reserve covers from $44^{\circ} 45^{\prime}$ to $45^{\circ} 02^{\prime} \mathrm{N}$, and from $20^{\circ} 55^{\prime}$ to $21^{\circ} 20^{\prime} \mathrm{E}$ (Štetić et al., 2021). Unusually large fluctuations in air temperature have been recorded there both during the year and during the day (Kovačev, 2014).

This protected area is characterized by a very rare duna relief, unique only to this protected area. Sand, which is a significant component of the soil here, has influenced the development of special flora and fauna, some of which are endemic and cannot be found in other protected areas in Vojvodina (Banat paeony, Pančić wormwood, bulrush, dwarf-steppe almond, sandy immortelle and juniper tree) (Popović et al., 2012; Štetić et al., 2021). Diverse and rare flora and fauna, the existence of wetlands and dunes are significant natural factors that can positively influence the development of nature-based tourism.

In the area of the reserve, there is a famous hunting ground "Deliblatska Peščara" with a total area of 31,036.55 ha, which represents enormous tourism potential. There are capacities in the area of the reserve that enable the development of ecotourism, excursion, rural, nautical, wine, sports, hunting and educational tourism. That can be possible with the accommodation capacities of the School-Recreational Center "Čardak" (130 beds) and hunting lodges, camps and rural households in Šumarak, Dubovac, Deliblato, Skorenovac and Kovin.

The SNR is also a unique protected area because it includes 7 health trails, intended for users of sports and recreational tourism, educational, eco and health tourism. The total length of the trails is about $50 \mathrm{~km}$ (Štetić et al., 2021). 


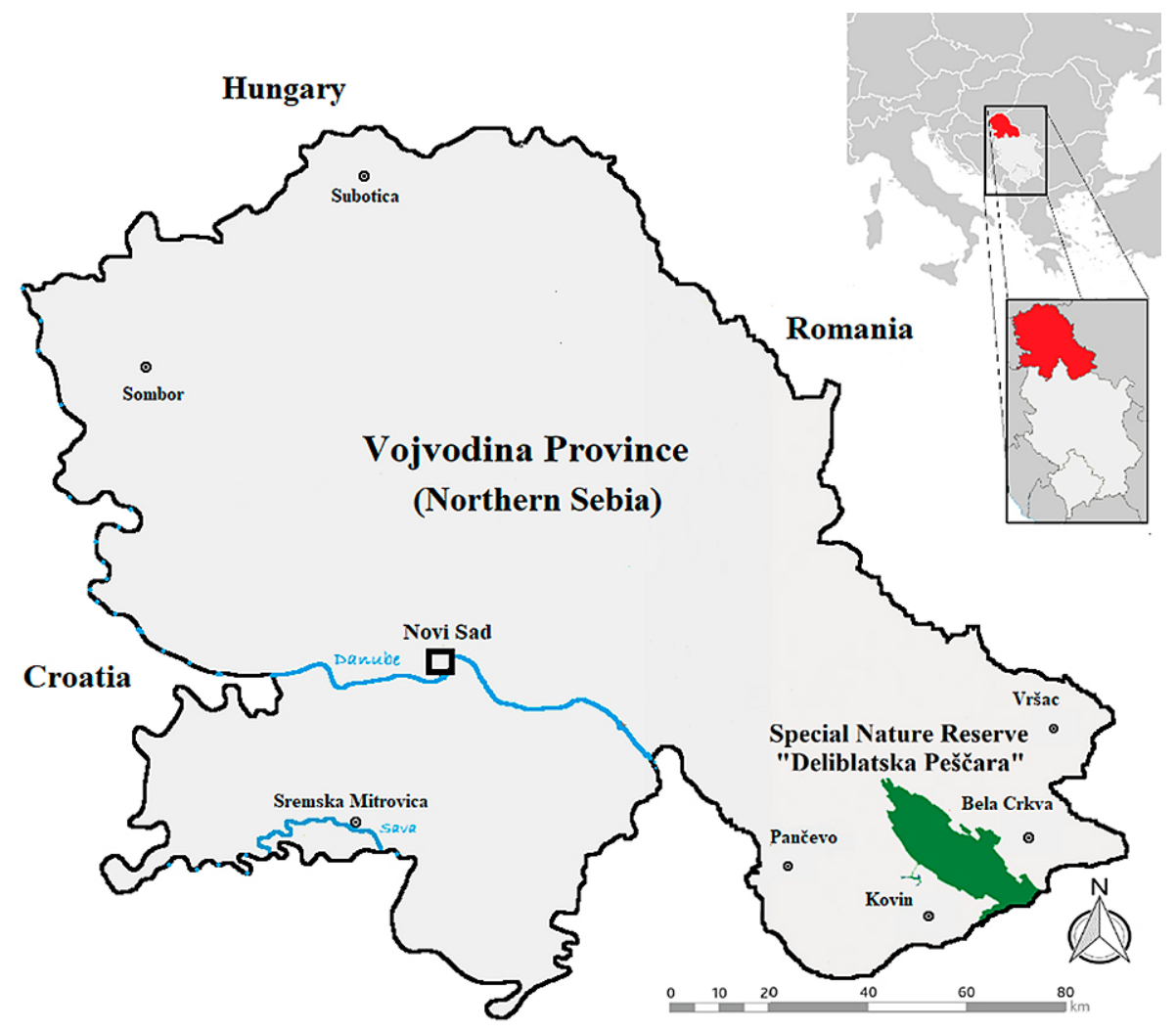

Figure 1. Location of Deliblatska peščara Special Nature Reserve with a position in the Republic of Serbia and in respect to the European Union Source: digitalized by authors

By analyzing all the natural and traffic factors mentioned above, we can conclude that the SNR has a favorable geographical position and good traffic connections with cities in Vojvodina and with the surrounding countries (Figure 1).

Some settlements near the reserve have significant cultural, monumental and archaeological heritage such as Dolovo, Deliblato, Grebenac, Dubovac,
Pločica, Banatski Karlovac, Alibunar and Izbište. The population of the settlement that covers the area of the reserve has a rich cultural tradition and folklore. Customs, local handicrafts, gastronomy, wine routes, original folk melodies and events, national diversity, language and religious affiliation, are significant socio-cultural tourism potential in this protected area (Štetić et al., 2021).

\section{Methods}

In this paper, the perception and satisfaction of residents with the state of sustainable tourism development in the SNR are analyzed. The survey included an examination of attitudes about the values and significance of twenty selected items for the state of sustainable tourism within this special nature reserve (Chin et al., 2000; Choi \& Sirakaya, 2006; Moore \& Polley, 2007; Schianetz \& Kavanagh, 2008; SowinskaŚwierkosz \& Chmielewski, 2014; Torres-Delgadoa \& Saarinen, 2014; Banos-Gonzales et al., 2016; Lee \& Hsieh, 2016; Sanchez et al., 2020).

\section{Sample}

The research used questionnaires with 20 statements on the state of sustainable tourism within the SNR, grouped into four dimensions of sustainability (environmental, economic, socio-cultural and institutional). Also, the questionnaires contain four questions concerning the direct satisfaction of residents with sustainable tourism development (Tables 2 and 3). The research models served to constitute the statements and questions in the questionnaire Scholtz et al., (2015), Cottrell et al., (2013), and Asmelash and Kumar (2019).

\section{Data Collection Procedure}

Written and online questionnaires were used in the survey. Residents' answers using a written questionnaire were collected in the field in personal contacts. Social networks were used to collect respons- 
es through online questionnaires, in order to obtain as many responses as possible from the residents of different ages and to comply with epidemiological measures to prevent the spread of COVID 19. The survey was conducted during April and May 2021. Quantitative methodology was applied using the Statistical Package for the Social Science (SPSS). Cronbach's Alpha analysis was used to test the reliability of the samples to measure all four dimensions of sustainability and the degree of satisfaction of the population with sustainable tourism development. Finally, the value of residents' satisfaction with the dimensions of sustainability was examined using regression analysis (Cottrell et al., 2013; Obradović et al., 2020).

\section{Data Analysis}

Using the analysis of attitudes and satisfaction of residents, the importance of certain natural, socio-cul- tural, communicative, receptive, economic and other factors within the tourism destination for the development of sustainable tourism was examined (Mearns, 2011; Rio \& Nunes, 2012).

The statements and questions were adapted to the survey of residents' perceptions and satisfaction with sustainable tourism development in the SNR. The respondents spoke about environmental, economic, socio-cultural, and institutional sustainability through 20 statements and four separate questions related to personal satisfaction. They expressed their satisfaction with sustainable tourism development in the questionnaire on a five-point Likert scale. Grade 1 indicates absolute disagreement, grade 5 indicates absolute agreement with the proposed statement, while grade 3 represents a neutral attitude (Maple et al., 2010; Puhakka \& Siikamäki, 2012; Scholtz et al., 2012; Dolnicar \& Grün, 2013; Kruger et al., 2013; Rasoolimanesh \& Jaafar, 2016).

\section{Results and discussion}

The total sample included 510 respondents. The survey of residents was conducted in 7 settlements located in the area of the SNR. The survey related to the SNR was conducted in the following settlements: Dolovo (130 respondents), Deliblato (125), Dubovac (85), Mramorak (78), Gaj (61), Šumarak (19) and Malo Bavanište (12). The socio-demographic structure of the respondents can be seen in Table 1 .

Table 1. Structure of Respondents

\begin{tabular}{|l|c|c|}
\hline Gender & Frequency & \multicolumn{2}{|c|}{ Percent } \\
\hline Male & 230 & \multicolumn{2}{|c|}{45.09} \\
\hline Female & 280 & \multicolumn{2}{|c|}{54.91} \\
\hline Total & 510 & \multicolumn{2}{|c|}{100.0} \\
\hline \multirow{2}{*}{ Education } & Frequency & \multicolumn{2}{|c|}{ Percent } \\
\hline Primary Education & 42 & \multicolumn{2}{|c|}{8.23} \\
\hline Secondary Education & 345 & \multicolumn{2}{|c|}{67.65} \\
\hline College Education & 84 & \multicolumn{2}{|c|}{16.47} \\
\hline Higher Education & 39 & \multicolumn{2}{|c|}{7.65} \\
\hline Total & 510 & \multicolumn{2}{|c|}{100} \\
\hline \multirow{2}{*}{ Age Structure } & $\mathrm{N}$ & \multicolumn{2}{|c|}{ Min } & Max \\
\cline { 2 - 4 } & 510 & \multicolumn{2}{|c|}{18} & 69 \\
\cline { 2 - 5 } & Mean & \multicolumn{2}{|c|}{ Std. Dev. } \\
\cline { 2 - 5 } & 37.56 & \multicolumn{2}{|c|}{16.234} \\
\hline Source: Author's calculation & & \multicolumn{2}{|c|}{}
\end{tabular}

Analyzing the data in Table 1, it can be concluded that women are in the majority (54.91\%). The average age is 37.56 (in the range of 18 to 69). Most respondents have secondary education $67.64 \%$, a total of
$8.23 \%$ have primary education, college education has $16.47 \%$, while higher education has $7.65 \%$. The majority of respondents are employed (86.4\%), then the unemployed (9.7\%), students (5.1\%) and retired (1.2\%).

The quantitative methodology included testing the reliability of variables, in order to test the dimensions of sustainability and satisfaction of the population with the sustainable development of tourism in the SNR. The indices were computed as variable means comprising each dimension (independent variables). The results of the respondents' answers according to 20 set statements grouped into four dimensions of sustainability, can be seen in Table 2 .

Analyzing the data in Table 2, it can be concluded that the results of the regression analysis application indicate different attitudes of respondents towards the four dimensions of sustainability. The ecological dimension (3.74) and Socio-cultural dimension (3.28) have the highest values. Among the highestrated statements in these two dimensions are: "There are facilities, services and activities available to tourists and the local community in the protected area" (4.11) and "There are tourist facilities without impacts on the environment" (3.69) in Ecological dimension; and "Tourists are interested in home products and crafts" (4.15), "Tourists are interested in historical sites" (4.02), "Tourists visit local cultural facilities and events" (3.67) and "Tourists are in contact with the local community" (3.54) in Socio-cultural dimension. The lowest values (below 3.0) have statements in the Economic dimension, specifically the claims: "Protected area tourism contributes to the employment 
Table 2. Respondents' perceptions of the dimensions of sustainable tourism

\begin{tabular}{|c|c|c|}
\hline \multirow{2}{*}{$\begin{array}{l}\text { Items } \\
\text { Dimensions of Sustainable Tourism }\end{array}$} & \multicolumn{2}{|c|}{ SNR $(n=510)$} \\
\hline & $\alpha$ & Mean \\
\hline Institutional Dimension & 0.631 & 3.17 \\
\hline $\begin{array}{l}\text { Tourists are guided through the protected area by trained guides and representatives of the local } \\
\text { population }\end{array}$ & & 3.11 \\
\hline $\begin{array}{l}\text { Tourists in the protected area can see the local brands (wineries, ethno houses, handicrafts, local } \\
\text { enterprises, etc.) }\end{array}$ & & 3.25 \\
\hline $\begin{array}{l}\text { In the protected area, the manager's instructions on nature protection and tourist activities are } \\
\text { followed }\end{array}$ & & 3.10 \\
\hline $\begin{array}{l}\text { Tourists are provided with information that reflects the history of the reserve, population and } \\
\text { settlements }\end{array}$ & & 3.21 \\
\hline Ecological Dimension & 0.681 & 3.74 \\
\hline There is the joint role of tourists and locals in protecting the area & & 3.44 \\
\hline $\begin{array}{l}\text { There are facilities, services and activities available to tourists and the local community in the } \\
\text { protected area }\end{array}$ & & 4.11 \\
\hline There are tourist facilities without impacts on the environment & & 3.69 \\
\hline Economic Dimension & 0.531 & 2.84 \\
\hline Tourism of the protected area benefits the local community & & 3.12 \\
\hline Tourism of the protected area supports the local economy & & 3.09 \\
\hline Tourism in the protected area contributes to the employment of the local population & & 2.11 \\
\hline Local products are available to tourists & & 3.51 \\
\hline Tourists support the payment of tickets to the protected area & & 3.22 \\
\hline Protected area tourism contributes to the employment of women & & 2.03 \\
\hline Socio-cultural Dimension & 0.603 & 3.28 \\
\hline Tourists are interested in home products and crafts & & 4.15 \\
\hline Tourists are in contact with the local community & & 3.54 \\
\hline Tourists are interested in local traditions and customs & & 3.02 \\
\hline Tourists visit local cultural facilities and events & & 3.67 \\
\hline Tourists are interested in historical sites & & 4.02 \\
\hline Tourists are interested in joint tourist activities with the local population & & 2.54 \\
\hline Due to tourism, the crime rate is lower & & 2.05 \\
\hline $\begin{array}{l}\text { Items measured on a 5-point Likert agreement scale } \\
\alpha-\text { Cronbach Alpha Reliability }\end{array}$ & & \\
\hline
\end{tabular}

Source: Author's calculation

of women" (2.03) and "Tourism in the protected area contributes to the employment of the local population" (2.11). The Institutional dimension represents the average value (3.17), while the statements with the highest value are: "Tourists in the protected area can see the local brands (wineries, ethno houses, handicrafts, local enterprises, etc.)" (3.25), and "Tourists are provided with information that reflects the history of the reserve, population and settlements" (3.21).

The Cronbach Alpha scores were 0.63 for the Institutional dimension (4 items), 0.68 for the Ecological dimension ( 3 items), 0.53 for the Economic dimension ( 6 items), 0.60 for the Socio-cultural dimension ( 7 items), and 0.62 for the satisfaction index for the SNR (Table 3). The Economic dimension has relatively lower reliability but it is accepted as valid in the research. Cotrel et al.,
2007 point out that an " $\alpha$ " lower than 0.60 can be accepted as reliable in studies, in which there are 6 or fewer items examined. From the above mentioned, in this study, all examined variables in all four dimensions of sustainability can be considered reliable.

From the data in Table 4, it can be concluded that the total mean value of the examined satisfaction of residents with the development of sustainable tourism in the SNR is 3.73. The highest values have the statements: "I am satisfied because this area is an important destination due to tourism" (4.41) and "I am satisfied because sustainable tourism in this area is important to me" (4.11). The lowest value has the satisfaction of residents with the impact of tourism on their quality of life and family (2.84). By applying regression analysis, it can be determined whether each 
Table 3. Scale items for the satisfaction index

\begin{tabular}{|l|l|l|}
\hline \multirow{2}{*}{ Satisfaction Index } & \multicolumn{2}{|l|}{ The SNR ( $\mathrm{n}=510)$} \\
\cline { 2 - 3 } & $\alpha$ & Mean \\
\hline & 0.621 & 3.73 \\
\hline I am satisfied because tourism in the protected area produces benefits for me and my family & 3.56 \\
\hline I am satisfied because sustainable tourism in this area is important & 4.11 \\
\hline I am satisfied because this area is a significant destination due to tourism & & 4.41 \\
\hline $\begin{array}{l}\text { I am satisfied because the quality of my life and the life of my family has improved owing to } \\
\text { tourism in this area }\end{array}$ & & 2.84 \\
\hline
\end{tabular}

Source: Author's calculation

dimension of sustainability contributes to the satisfaction of residents with sustainable tourism development. (Cottrell et al., 2007; Sharpley, 2014; Vargas-Sánchez et al., 2015; Obradović et al., 2020). The assumption was supported with all four-dimensional scores as significant predictors of residents' satisfaction with tourism (Huayhuaca et al., 2010; Obradović et al., 2020) accounting for $32 \%$ of the variances explained (R2=0,321) (Table 4).

Table 4 shows the data obtained after applying regression analysis of residents' responses and their attitudes towards the stated claims and satisfaction with the four dimensions of sustainability. It can be concluded that each dimension of sustainability signifi-
Table 4. Regression analysis of the SNR on residents satisfaction

\begin{tabular}{|l|c|c|}
\hline \multirow{2}{*}{$\begin{array}{l}\text { Satisfaction with tourism } \\
\text { items }\end{array}$} & \multicolumn{2}{|c|}{ The SNR $(\mathrm{n}=510)$} \\
\cline { 2 - 3 } & $\boldsymbol{\beta}^{\text {' }}$ & $\boldsymbol{p}$-value \\
\hline Institutional dimension & 0.156 & 0.001 \\
\hline Ecological dimension & 0.223 & 0.001 \\
\hline Economic dimension & 0.149 & 0.001 \\
\hline Socio-cultural dimension & 0.196 & 0.001 \\
\hline 'Standardised $\beta$ value used $\mathrm{R}^{2}=0,321$ \\
\hline
\end{tabular}

Source: Author's calculation

cantly contributes to satisfaction of residents with sustainable tourism development.

\section{Conclusion}

The paper examines the perceived attitudes and satisfaction of residents with the state of sustainable tourism. The respondents expressed their views on institutional, environmental, economic and socio-cultural sustainability. After applying the quantitative methodology and analyzing the obtained results, it can be concluded that each of the four dimensions of sustainability has a higher or lower impact on the satisfaction of residents with the state of sustainable tourism (Table 2). The ecological dimension of sustainability was rated the highest marks. Their opinions indicate that residents particularly value the state of nature as well as the activities for nature protection. This result provides an opportunity to increase tourist traffic by planning the development of nature-based forms of tourism, among which the most important may be ecotourism, scientific tourism, trips, sports, birdwatching, hiking, trekking, etc. Comparing these results with those obtained by Obradović et al., (2021) and Obradović and Stojanović (2021), tourism destination sustainability can undoubtedly be achieved if the local population is actively involved in the planning of nature-based tourism.

Socio-cultural sustainability is also assessed as significant by the residents. The activities that indicate the interest of tourists in local events, domestic products and cultural and historical heritage are singled out as lower-rated. The individual values of sociocultural sustainability (Table 2) show that planned measures for sustainable tourism should include local heritage and customs in the tourism offer and interaction of local community representatives and tourists through various tourism activities. This SNR possesses many tourist attributes that can be a good model for the development of cultural, wine, gastronomic, and event tourism.

Comparative analysis with the results of research Obradović et al., (2021), Obradović and Stojanović (2021), indicates that the local population plays a significant role in the mentioned activities. By considering residents attitudes about sustainable tourism, it is possible to devise local community management strategies. They can result in strengthening the socio-cultural Sustainability of this tourism destination. We can improve the institutional sustainability of this destination by enriching the tourism offer with local products, intensifying the management processes in this nature reserve, referring to the improvement of protection measures with the aim of nature conservation. The results of the economic dimension enable us to plan those activ- 
ities that will result in economic benefits for residents through the planned tourism development measures.

The impacts on women's employment and economic impacts on individuals and their families single out as less rated items of economic sustainability. The reason for such influences lies in tourist consumption and tourist traffic. Higher tourist spending can be a direct result of higher tourist visits to this tourism destination. This can be achieved by proper planning and promotion of tourism in this nature reserve, which aims to preserve nature and its natural and social elements. The increasing tourist movements create conditions for higher incomes from tourism and new jobs for the local population. In this survey, the residents stated that the development of sustainable tourism is important for them. Certain items have lower values, which is the basis for the development of planned measures for the development of sustainable tourism forms. The previously performed compara- tive analysis indicates a coincidence with the research results in this paper. The local population is perfectly aware of the importance of sustainable tourism. Also, the local population can identify certain weaknesses in tourism development, which can be corrected by proper planning of tourism development. Therefore, one of the conclusions of this paper should be that the role of the local population in sustainable tourism development is essential. The authors will focus their future study on examining the possibilities of developing various activities that can best improve individual dimensions of sustainability. When the development of tourism achieves environmental, economic, sociocultural and institutional benefits for all tourism entities, it can be concluded that all the postulates that tourism can be categorized as sustainable are met. Such a tourism destination represents an exceptional national tourism potential for $21^{\text {st }}$ century tourism.

\section{References}

Agyeiwaah, E., McKercher, B., \& Suntikul, W. (2017). Identifying core indicators of sustainable tourism: A path forward? Tourism Management Perspectives, 24, 26-33. https://doi.org/10.1016/j.tmp.2017.07.005

Aquino, R.S. (2019). Transforming travel: realising the potential of sustainable tourism. Journal of Ecotourism, 18(2), 193-195. https://doi.org/10.1080/147 $\underline{24049.2018 .1465258}$

Asmelash, A.G., \& Kumar, S. (2019). The structural relationship between tourist satisfaction and sustainable heritage tourism development in Tigrai, Ethiopia. Heliyon, 5(3), E01335. https://doi.org/10.1016/j. heliyon.2019.e01335

Banos-Gonzales, I., Martinez-Fernandez, J., \& Esteve-.Selma, M.A. (2016). Using dynamic sustainability indicators to assess environmental policy measures in Biosphere Reserves. Ecological Indicators, 67, 565-576. https://doi.org/10.1016/j.ecolind.2016.03.021

Bello, F.G., Carr, N., \& Lovelock, B. (2016). Community participation framework for protected areabased tourism planning. Tourism Planning \& Development, 13(4), 469-485. https://doi.org/10.1080/ 21568316.2015.1136838

Buckley, R. (2003). Ecological indicators of tourist impacts in parks. Journal of Ecotourism, 2(1), 54-66. https://doi.org/10.1080/14724040308668133

Ceron, J., \& Dubois, G. (2003). Tourism and sustainable development indicators: the gap between theoretical demands and practical achievement. Current Issues in Tourism, 6(1), 54-75. https://doi. org/10.1080/13683500308667944
Chávez-Cortés, M., \& Maya, J.A.A. (2010). Identifying and structuring values to guide the choice of sustainability indicators for tourism development. Sustainability, 2(9), 3074-3099. https://doi. org/10.3390/su2093074

Chin, C.L.M., Moore, S.A., Wallington, T.J., \& Dowling, R. (2000). Ecotourism in Bako National Park, Borneo: visitors' perspectives on environmental impacts and their management. Journal of Sustainable Tourism, 8(1), 20-35. https://doi. org/10.1080/09669580008667347

Choi, H.C., \& Sirakaya, E. (2006). Sustainability indicators for managing community tourism. Tourism Management, 27(6), 1274-1289. https://doi. org/10.1016/j.tourman.2005.05.018

Cottrell, S.P., Vaske, J.J., \& Roemer, J.M. (2013). Resident satisfaction with sustainable tourism: The case of Frankenwald Nature Park, Germany. Tourism Management Perspectives, 8, 42-48. https://doi. org/10.1016/j.tmp.2013.05.005

Cottrell, S.P., Vaske, J.J., \& Shen, F. (2007). Modeling resident perceptions of sustainable tourism development: Applications in Holland and China. Journal of China Tourism Research, 3(2), 219-234.

Dolnicar, S., \& Grün, B. (2013). Validly measuring destination images in survey studies. Journal of Travel Research, 52(1), 3-14. https://doi. org/10.1177\%2F0047287512457267

Eagles, P.F.J. (2002). Trends in park tourism: economics, finance and management. Journal of Sustainable Tourism, 10(2), 132-153. https://doi. org/10.1080/09669580208667158 
Font, X., Sanabria, R., \& Skinner, E. (2003). Sustainable tourism and ecotourism certification: raising standards and benefits. Journal of Ecotourism, 2(3), 213218. https://doi.org/10.1080/14724040308668145

Hall, C.M. (2019). Constructing sustainable tourism development: the 2030 agenda and the managerial ecology of sustainable tourism. Journal of Sustainable Tourism, 27(7), 1044-1060. https://doi.org/10.1 080/09669582.2018.1560456

Huayhuaca, C., Cottrell, S., Raadik, J., \& Gradl, S. (2010). Resident perceptions of sustainable tourism development: Frankenwald Nature Park, Germany. International Journal of Tourism Policy, 3(2), 125141. http://dx.doi.org/10.1504/IJTP.2010.034207

Jojić-Glavonjić, T., Brankov, J., \& Miljanović, D. (2018). Residents'perception toward protected areas - Carska Bara Special Nature Reserve (Vojvodina, Serbia). Geographica Pannonica, 22(6), 246-275. https://doi.org/10.5937/gp22-18960

Kovačev, N., Romelić, J., Pivac, T., \& Lukić, T. (2014). Trips as primary and associated forms of other tourist Deliblato Sands movement. Researches Review of the Department of Geography, Tourism and Hotel Management, 43(2), 130-147.

Kruger, M., Viljoen, A., \& Saayman, M. (2017). Who visits the Kruger National Park and why? Identifying target markets. Journal of Travel \& Tourism Marketing, 34(3), 312-340. https://doi.org/10.1080/1 $\underline{0548408.2016 .1156618}$

Lee, T.H., \& Hsieh, H.P. (2016). Indicators of sustainable tourism: A case study from a Taiwan's wetland. Ecological Indicators, 67, 779-787. https://doi. org/10.1016/j.ecolind.2016.03.023

Maksin, M., Ristić, V., Nenković-Riznić, M., \& Mićić, S. (2018). The role of zoning in the strategic planning of protected areas: Lessons learnt from EU countries and Serbia. European Planning Studies, 26(4), 838-872. https://doi.org/10.1080/09654313.2 $\underline{018.1426736}$

Maple, L.C., Eagles, P.F.J., \& Rolfe, H. (2010). Birdwatchers' specialisation characteristics and national park tourism planning. Journal of Ecotourism, 9(3), 219238. https://doi.org/10.1080/14724040903370213

McCool, S.F., Moisey, R.N., \& Nickerson, N.P. (2001). What should tourism sustain? The disconnect with industry perceptions of useful indicators. Journal of Travel Research, 40(2), 124-131. https://doi.org/10 $.1177 \% 2 \mathrm{~F} 004728750104000202$

Mearns, K.F. (2011). Using sustainable tourism indicators to measure the sustainability of a communitybased ecotourism venture: Malealea Lodge \& Pony Trek Centre, Lesotho. Tourism Review International, 15(1-2), 135-147. https://doi.org/10.3727/154427 $\underline{211 X 13139345020499}$
Moore, C.A., \& Polley, A. (2007). Defining indicators and standards for tourism impacts in protected areas: Cape Range National Park, Australia. Environmental Management, 39(3), 291-300. https://doi. org/10.1007/s00267-005-0191-5

Obradović, S., \& Stojanović, V. (2021). Measuring residents' attitude toward sustainable tourism development: a case study of the Gradac River gorge, Valjevo (Serbia). Tourism Recreation Research, https:// doi.org/10.1080/02508281.2020.1870073

Obradović, S., Stojanović, V., Kovačić, S., Jovanović, T., Pantelić, M., \& Vujićić, M. (2021). Assessment of residents' attitudes toward sustainable tourism development - A case study of Bačko Podunavlje Biosphere Reserve, Serbia. Journal of Outdoor Recreation and Tourism, 35, 100384. https://doi. org/10.1016/j.jort.2021.100384

Obradović, S., Tešin, A., Božović, T., \& Milošević, D. (2020). Residents' perceptions of and satisfaction with tourism development: a case study of the Uvac Special Nature Reserve, Serbia. Tourism and Hospitality Research, 21(1), 31-43. https://doi. org/10.1177\%2F1467358420946789

Pavić, D., Jakovljević, D., \& Krajić, A. (2016). Local Reactions Concerning Serbia's Obedska Bara Na-ture Reserve. Polish Journal of Environmental Studies, 25(1), 273-282. https://doi.org/10.15244/pjoes/60501

Popović, Z., Smiljanić, M., Matić, R., Kostić, M., Nikić, P., \& Bojović, S. (2012). Phytotherapeutical plants from the Deliblato Sands (Serbia): traditional pharmacopoeia and implications for conservation. Indian Journal of Traditional Knowledge, 11(3), 385-400.

Puhakka, R., \& Siikamäki, P. (2012). Nature tourists' response to ecolabels in Oulanka PAN Park, Finland. Journal of Ecotourism, 11(1), 56-73. https://doi. org/10.1080/14724049.2011.647917

Queiroz, R.E., Guerreiro, J., \& Ventura, M.A. (2014). Demand of the Tourists Visiting Protected Areas in Small Oceanic Islands: the Azores Case Study (Portugal). Environment, Development and Sustainability, 16(5), 1119-1135. https://doi.org/10.1007/ s10668-014-9516-y

Rasoolimanesh, S.M., \& Jaafar, M. (2016). Sustainable tourism development and residents' perceptions in World Heritage Site destinations. Asia Pacific Journal of Tourism Research, 22(1), 34-48. https://doi.or $\mathrm{g} / 10.1080 / 10941665.2016 .1175491$

Rio, D., \& Nunes, L.M. (2012). Monitoring and evaluation tool for tourism destinations. Tourism Management Perspectives, 4, 64-66. https://doi. org/10.1016/j.tmp.2012.04.002

Sæpórsdóttir, A.D., \& Hall, C.M. (2021). Visitor satisfaction in wilderness in times of overtourism: a longitudinal study. Journal of Sustainable Tourism, 29(1), 123141. https://doi.org/10.1080/09669582.2020.1817050 
Sanchez, M.L., Cabrera, A.T., \& Gomez del Pulgar, M.L. (2020). The potential role of cultural ecosystem services in heritage research through a set of indicators. Ecological Indicators, 117, 106670. https://doi.org/10.1016/j.ecolind.2020.106670

Schianetz, K., \& Kavanagh, L. (2008). Sustainability indicators for tourism destinations: a complex adaptive systems approach using systemic indicator systems. Journal of Sustainable Tourism, 16(6), 601628. http://dx.doi.org/10.1080/09669580802159651

Scholtz, M., Kruger, M., \& Saayman, M. (2015). Determinants of visitor length of stay at three coastal national parks in South Africa. Journal of Ecotourism, 14(1), 21-47. https://doi.org/10.1080/14724049. 2015.1023730

Scholtz, M., Saayman, M., \& Kruger, M. (2012). The influence of the economic recession on visitors to the Kruger National Park. Journal of Economic and Financial Sciences, 5(1), 247-270. https://doi. org/10.4102/jef.v5i1.316

Sharpley, R. (2000). Tourism and sustainable development: exploring the theoretical divide. Journal of Sustainable Tourism, 8(1), 1-19. https://doi. org/10.1080/09669580008667346

Sharpley, R. (2014). Host perceptions of tourism: a review of the research. Tourism Management, 42, 3749. https://doi.org/10.1016/j.tourman.2013.10.007

Sowinska-Świerkosz, B., \& Chmielewski, T.J. (2014). Comparative assessment of public opinion on the landscape quality of two biosphere reserves in Europe. Environmental Management, 54, 531-556. https://doi.org/10.1007/s00267-014-0316-9

Spangenberg, J.H. (2002). Environmental space and the prism of sustainability: Frameworks for indicators measuring sustainable development. Ecological Indicators, 2(3), 295-309. https://doi.org/10.1016/ S1470-160X(02)00065-1

Stojanović, V., Lazić, L., \& Dunjić, J. (2018). Nature protection and sustainable tourism interaction in selected Ramsar sites in Vojvodina (Northern Serbia). Geographica Pannonica, 22(3), 201-207. https:// doi.org/10.5937/gp22-16637

Stojanović, V., Mijatov, M., Dunjić, J., Lazić, L., Dragin, A., Milić, D., \& Obradović, S. (2021). Ecotourism impact assessment on environment in protected areas of Serbia: A case study of Gornje Podunavlje Special Nature Reserve. Geographica Pannonica, 25(3), 157-167. https://doi.org/10.5937/gp25-32288

Štetić, S., Trišić, I., \& Gvozden, I. (2021). Ecotourism of the Special Nature Reserve "Deliblatska Peščara" in the conditions of the COVID-19 pandemic. Ecologica, 28(102), 208-214. https://doi.org/10.18485/ ecologica.2021.28.102.10

Štetić, S., Trišić, I., \& Nedelcu, A. (2019). Natural potentials of significance for the sustainable tourism development - the focus on the special nature reserve. Journal of the Geographical Institute "Jovan Cvijić" SASA, 69(3), 279-287. https://doi. org/10.2298/IJGI1903279S

Tanguay, G.A., Rajaonson, J., \& Therrien, M.C. (2013). Sustainable tourism indicators: selection criteria for policy implementation and scientific recognition. Journal of Sustainable Tourism, 21(6), 862-879. https://doi.org/10.1080/09669582.2012.742531

Torres-Delgadoa, A., \& Saarinen, J. (2014). Using indicators to assess sustainable tourism development: a review. Tourism Geographies, 16(1), 31-47. https:// doi.org/10.1080/14616688.2013.867530

Trišić, I. (2020). Using indicators to assess sustainable tourism development - the case of protected natural areas of Vojvodina (Northern Serbia). Turizam, 24(4), 178-193. https://doi.org/10.5937/turizam24-26080

Trišić, I., Štetić, S., \& Maksin, M. (2020). The significance of protected natural areas for the tourism of the Vojvodina Province (Northern Serbia) - relevant factors analysis of the sustainable tourism development. SPATIUM, 43, 1-7. https://doi. org/10.2298/SPAT2043001T

Trišić, I., Štetić, S., Privitera, D., Petrović, M.D., Maksin, M., Vujović, S., Jovanović, Z., \& Kalinić, M. (2021). Perspectives on sustainable tourism development in the hotel industry - a case study from Southern Europe. Sustainability, 13(10), 5563. https://doi.org/10.3390/su13105563

Twining-Ward, L., \& Butler, R. (2002). Implementing STD on a small island: development and use of sustainable tourism development indicators in Samoa. Journal of Sustainable Tourism, 10(5), 363-387. https://doi.org/10.1080/09669580208667174

Vargas-Sánchez A., Valle, P.O., Mendes J.C., \& Silva, J.A. (2015). Residents' attitude and level of destination development: an international comparison. Tourism Management, 48, 199-210. https://doi. org/10.1016/j.tourman.2014.11.005

Vučetić, A. (2018). Importance of environmental indicators of sustainable development in the transitional selective tourism destination. International Journal of Tourism Research, 20(3), 317-325. https://doi. org/10.1002/jtr.2183 